\title{
The Challenge of UNASUR Member Countries to Replace ICSID Arbitration
}

\author{
Silvia Karina Fiezzoni ${ }^{1,2,3}$ \\ ${ }^{1}$ Dalian Maritime University, Dalian, China; ${ }^{2}$ School of Law, Buenos Aires University, Buenos Aires, Argentina; ${ }^{3}$ National Institute \\ of High Studies, Quito, Ecuador. \\ Email: karina_fiezzoni@yahoo.com.ar
}

Received July 25 ${ }^{\text {th }}$, 2011; revised August 23 ${ }^{\text {rd }}, 2011$; accepted $1^{\text {st }}, 2011$.

\begin{abstract}
In the 2000s, the financial crisis in Argentina and several nationalizations carried out by governments in South America have spawned a large number of claims before International Centre for Settlement of Investment Disputes (ICSID). Latin Americans began to look at ICSID critically, there have been complaints about ICSID's connections with the World Bank; non-commercial interests, such as health or environmental protection, have not received adequate attention in the arbitration cases; a lack of transparency by arbitration panels; and the absence of an appeals process, but only a limited annulment procedure. This situation generates impacts upon the overall due process of ICSID arbitrations and Latin American hostility against ICSID, such the Bolivarian Alliance for the Peoples of our America Peoples' Trade Treaty (ALBA-TCP) Declaration to denounce ICSID Convention and the firm intention of Union of South American Nations (UNASUR) countries to create a regional arbitration centre to replace ICSID arbitration.
\end{abstract}

Keywords: UNASUR, Challenge, ICSID

\section{Introduction}

The past two decades have seen a virtual explosion in investor-State arbitrations before ICSID. A significant proportion of the total ICSID caseload are against Latin American States (39\% cases of the total ICSID),${ }^{1}$ involved claims that have arisen from regulatory measures in matters of public interest. Among Latin American countries, Argentina alone accounts for 49 cases, Venezuela 23 cases, Mexico 14 cases $^{2}$ and Ecuador 14 cases [1]. In relation to UNASUR, 9 of 12 its member countries faced 117 cases before ICSID, mostly with activities related to natural resources. ${ }^{3}$

Nowadays, Latin American countries have begun to look at the ICSID critically, formulating a list of complaints such as: ICSID's connection with the World Bank; concerns by some Latin American States that hostility

${ }^{1}$ Considering the following Latin American Countries: Argentina (49 cases), Bolivia (4 cases), Brazil (is not member of ICSID), Chile (3 cases), Colombia (no cases), Cuba (is not member of ICSID), Costa Rica (5 cases), Dominican Republic (has not ratified the ICSID convention), Ecuador (14 cases), El Salvador (3 cases), Guatemala (3 cases), Honduras (3 cases), Mexico (14 cases), Nicaragua (1 case), Panama (1 case), Paraguay (3 cases), Peru (10 cases), Puerto Rico (no cases), Uruguay (1 case) and Venezuela (23 cases) [1].

${ }^{2}$ Mexico is not member of ICSID but has cases before ICSID under the North American Free Trade Agreement (NAFTA).

${ }^{3}$ Only Brazil, Surinam and Colombia do not have cases before ICSID. toward ICSID may hamper access to World Bank credit; non-commercial interests, such as health or environmental protection, have not received adequate attention in the arbitration cases; a lack of transparency by arbitration panels; a shadow of arbitrator bias in favor of the investor, with different ad hoc tribunals analyzing similar cases reaching disparate results; the absence of an appeals process, but only a limited annulment procedure; failure to take into account situations of massive economic downturns and the cost of the litigation [2]. The current movement in Latin American countries, thus, is trying to delimit or/and exclude the jurisdiction of the ICSID [3] and is declaring the necessity of the creation of Arbitration Centre in ALBA-TCP and in UNASUR.

It will be important for the People's Republic of China to follow as the current movement originated in Latin American countries against ICSID, considering that Chinese FDI to the region increased approximately 1,500 percent from US\$21.86 million in 2003 to US\$349.55 million in 2009, becoming the region's third largest FDI provider. ${ }^{4}$

\footnotetext{
${ }^{4}$ The leading recipients of Chinese FDI in Latin America from 2003 to the first semester of 2010 were Brazil (41 percent), Venezuela (15 percent), Peru (12 percent), Argentina (11 percent) and Chile (2 percent). The 90 percent of China's investment in the region has gone to natural resource extraction. In 2010 alone, China spent $\$ 13.3$ billion on oil and gas deals in countries such as Ecuador, Argentina, and Venezuela. [4].
} 
The object of this paper is to analyze the situation of some Latin American countries' countermeasures against ICSID and the UNASUR Arbitration Centre Rules proposed by Ecuador.

\section{The Challenges of Latin American Countries against ICSID}

Latin America began to look at the ICSID critically, complaining about political factors such as, the ICSID's connection with the World Bank; concerns that the hostility toward ICSID may hamper access to World Bank credit and a shadow of arbitrator bias in favor of the investor [2]. Moreover, the ICSID tribunals consider trade aspects, but do not integrate criteria, e.g. political, economic and social aspects that constitute the framework of the cases. Thus, ICSID's decisions and awards lack of contextualization of disputes and hence the decisions are detached from social, cultural, political and economic factors [5].

In relation to the ICSID proceedings, Latin American countries make the followings observations:

1. The regime of the ICSID arbitrations in investment does not work as a system, because ad-hoc tribunals analyze similar cases reaching disparate results. Moreover, the ICSID tribunals coexist without hierarchy and are not subject to consolidation cases nor appeals or any other form of external control by a supervisory body that could ensure consistency in the decision making process. One example of the necessity of an appeal mechanism is the case Repsol v. Petroecuador, where the Ad hoc Committee, basing its findings on the earlier annulment decisions, refused to annul the award on the grounds of the tribunal's alleged manifest excess of power, and noted that even if: "Tribunal had erroneously applied the laws of Ecuador, it should be recalled that, in ICSID's annulment system, the errors made in the application of a law [...] do not constitute [...] grounds for annulment of an award. [...] the latter must not be confused with an appeal," which is not available pursuant to Article 53 of the Convention. ${ }^{5}$ In relation to the lack of consistency in the decisions, it is possible to mention CMS v. Argen-

\footnotetext{
${ }^{5}$ See Repsol YPF Ecuador S.A. v. Empresa Estatal Petróleos del Ecuador (Petroecuador) (ICSID Case No. ARB/01/10) Decision on the Application for Annulment (January 8, 2007), para 38.

6، The Tribunal had already decided that Argentina had breached its international obligations under Article II(2)(a) and Article II(2)(c) of the BIT. It also decided that in the present case there was no state of necessity and did so in terms which, by necessary inference, excluded also the application of Article XI. Thus, under the well-known principle of international law recalled in Article 1 of the ILC Articles, Argentina was responsible for the wrongful measures it had taken.[..] The Committee concludes that, whatever may have been the errors made in this respect by the Tribunal, there is no manifest excess of powers or lack of reasoning in the part of the Award concerning Article XI of the BIT and state of necessity under customary international law.” See CMS Gas Transmission Company v. Argentine Republic (ICSID Case No. ARB/01/8). Decision of the ad hoc Committee on the Application for Annulment of the Argentine Republic, Sep 25, 2007, at para 149-150.
}

tina $^{6}$ and in LG\&E v. Argentina, ${ }^{7}$ the two tribunals, while reaching similar conclusions on the substantive treatment standards, but came to a diametrically opposed result on the question whether Argentina had been in a state of necessity during a specific period of time relevant to the dispute.

2. Lack impartiality of the proceedings and possible conflict of interests. The rules governing the choice and the challenge of the arbitrator before the ICSID provoke objections in detriment of ICSID impartiality. According to ICSID Rules, the presiding arbitrator can be chosen by agreement of both parties, and where the parties cannot agree, the Chairman of the ICSID Administrative Council (who is also the President of the World Bank) makes the final appointment [6]. It is important to consider the close relationship that exists between the ICSID and the World Bank Group, which in some cases may have an equity share or some regulatory influence over the investor. The World Bank includes entities (the International Bank for Reconstruction and Development and International Development Association -IDA-) which have been active in providing conditioned loans to impose structural adjustments on governments that directly favor the role of foreign investors. Sometimes the World Bank is a direct investor itself, through its International Finance Corporation (IFC). For example the case Aguas Argentinas, SA v. Republic of Argentina, the International Bank for Reconstruction and Development had played a key role in the design of the regulatory framework for public services under concession and in the privatization process, and the IFC held a percentage of Aguas Argentinas S.A. equity shares [7]. Thus, it is criticized that the World Bank is sometimes both judge and party to the ICSID proceedings.

In relation to the disqualification of the arbitrator the Rule 6(2) of the ICSID arbitration Rules requires an arbitrator to sign a declaration which includes a disclosure of his/her past and professional, business and other relationships with the parties and any other circumstances which might cause the arbitrator's reliability for independent judgment to be questioned by a party. The ICSID Rules, however, do not contain a list nor provide any guidance, on the situations or relationships that ought to be disclosed under Rule 6(2). The phrase "any other circumstance" is potentially very broad.

Moreover, Article 57 of the ICSID Convention provides that a party may propose that an arbitrator be disqualified on the basis "of any fact indicating a manifest

\footnotetext{
7"Between 1 December 2001 and 26 April 2003, Argentina was in a state of necessity, for which reason it shall be exempted from the payment of compensation for damages incurred during that period”. See LG\&E Energy Corp., LG\&E Capital Corp. and LG\&E International Inc v. Argentine Republic (ICSID Case No. ARB/02/1). Decision on Liability, October 3, 2006, at para. 267.
} 
lack of the qualities required by paragraph 1 of Article 14 . The need to show a "manifest lack of the qualities required" is a decidedly higher threshold to satisfy when set against the standards in other arbitral rules, such as United Nations Commission on International Trade Law (UNCITRAL) Rules [8]. As illustration of the difference between ICSID and UNCITRAL Rules, can be found in two challenges to Gabrielle Kaufmann Kohler raised by the respondent in two separate investment treaty proceedings against Argentina. The respondent called into question Kaufmann Kohler's qualifications when it learned that she served on the board of directors of the Swiss bank UBS. The conflicts problem in Sociedad General de Aguas de Barcelona S.A. and Interagua Servicios Integrales de Agua S.A. v. Argentine Republic arose from UBS's portfolio investments in shares of claimant companies $(2.38 \%$ of Vivendi and $2.1 \%$ of Suez). Argentina pointed out that Kaufmann Kohler received part of her compensation for her work on the board in UBS stock, and argued on this basis that she effectively held shares in the claimants. As a shareholder, Kaufmann Kohler arguably stood to benefit financially from an award against Argentina. The Tribunal was operating under both the UNCITRAL and the ICSID Rules, due to different terms of the applicable treaties. ${ }^{8}$ The two coarbitrators who adjudicated the challenge appear to have considered the ICSID standard for conflicts of interest to be more permissive than that applicable under the UNCITRAL Rules. The arbitrators concluded that the UNCITRAL Rules mandate disqualification where a reasonable and informed person would have justifiable doubts as to the challenge to the arbitrator's independence and impartiality. By contrast, the arbitrators considered that, under the ICSID framework, the challenging party must establish facts that make it obvious and highly probable, not just possible, that the arbitrator's independent and impartial judgment would be unreliable [9].

3. Lack of transparency. ICSID has exhibited a lack of transparency in proceedings because in the context of investor-State arbitrations, confidentiality can be perceived as a threat to justice when the public is denied access to information. Closed hearings, especially in arbitrations that involve a critical public interest, are criticized widely as antithetical to the democratic process [10].

4. High costs of the defense in ICSID arbitration. The defense of the State ends up being very costly, given the necessity to contract legal representation in the United

\footnotetext{
${ }^{8}$ Suez, Sociedad General de Aguas de Barcelona S.A. and Vivendi Universal S.A v. Argentine Republic (ICSID Case No. ARB/03/19) and Suez, Sociedad General de Aguas de Barcelona S.A. and Interagua Servicios Integrales de Agua S.A. v. Argentine Republic (ICSID Case No. ARB/03/17), were subject to ICSID arbitration, while the case of AWG Group Limited v. The Argentine Republic had to proceed under the UNCITRAL Arbitration Rules [9].
}

States. It is said that every case costs the State 4 million dollars. ${ }^{9}$ Moreover, the revenues of the suing companies are often greater than the GNP of defendant countries. For example, Aguas del Tunari/Bechtel reported revenues three times greater than Bolivia's GNP at the time it filed suit against Bolivia at ICSID. Shell, which filed charges against Nicaragua, had revenues 62 times the GNP of that country [12].

\section{ICSID \& Latin American Countries' Relations}

Under the Calvo Doctrine's influence, ${ }^{10}$ Latin American countries initially showed a widespread rejection of the ICSID Convention. In the mid sixties Latin America manifested its opposition, in bloc, to the World Bank's project to create an international agency specializing in settling investment disputes [2]. Latin American countries' rejection of the ICSID was known as the "No of Tokyo." This collective position was delivered at the 1964 Annual Meeting of the World Bank in Tokyo by the Chilean delegate on behalf of all the Latin American countries. Similar negative attitudes towards international arbitration were reflected in Decision No. 24, adopted in 1970 by the Commission of the Cartagena Board of the Andean Pact. The Decision provided an outright prohibition against the removal from the national jurisdictions of the member States of any dispute arising out of foreign investments or transfer of technology. The principles of Decision No 24 were reiterated in the Charter of Economic Rights and Duties of States adopted by the United Nations General Assembly in 1974 [14].

In the 1960s and 1970s, many Latin American countries (especially Argentina, Brazil and Mexico) borrowed to support development projects and programs in their countries. Latin American debt quadrupled from USD 75 billion in external debt in the mid 1970s to USD 315 billion by the early 1980s. When trade imbalances and an advancing world recession raising United States and European interest rates, many of the region's countries could no longer pay their foreign debt and the situation finally imploded in the 1980s. Coupled with a world economic recession, brought on in large part by the petroleum crisis of the 1980s, foreign credits to the region came to a halt and lending institutions began to formulate new rules and policies for loan programs for Latin American countries. Many loans became conditional upon the

\footnotetext{
${ }^{9}$ Reason invoked by Bolivia to denounce ICSID [11].

${ }^{10}$ Argentinean jurist, Carlos Calvo, formulated a doctrine that prevented foreigners from claiming more rights and privileges than those afforded to national citizens and the foreign governments should not violate the laws of sovereign states in an attempt to enforce its citizen's private claims. Carlos Calvo published his doctrine as part of a six-volume treatise entitled Le droit international theorique et pratique between 1868 and 1896 [13].
} 
borrowing country's adoption of privatization programs and signing treaties and conventions that would guarantee protection to foreign investors in those countries, as well as assuring the use of neutral forums for dispute resolution arising from the new investor-State relationships, like ICSID. Many countries, jolted by the crisis, were ready to accept the new conditions set by these institutions and agreed to adopt economic plans that were designed to attract FDI and guide them out of their indebtedness [10]. Thus, in the 1980s these countries started to change their position, the first Latin American countries to join the Convention were Ecuador, Honduras, and El Salvador. In the 1990s the rest of the Latin American countries, with the exceptions of Mexico, ${ }^{11}$ Cuba, Brazil, Puerto Rico and Dominican Republic (which has not ratified ICSID yet) [16], joined the ICSID Convention and entered into several Bilateral Investment Treaties (BITs) with other nations.

In the 2000s, the financial crisis in Argentina and several expropriations and nationalizations carried out by governments in South America have spawned a large number of claims before ICSID, brought primarily by U.S. and European investors.

In 2007 ALBA-TCP (which is a Latin American organization established as an alternative to the proposed Free Trade Area of the Americas) ${ }^{12}$ during its 5th Annual Summit, the proposal of Bolivian President Evo Morales to withdraw ICSID Convention was approved by Venezuela, Nicaragua and Bolivia. In relation to ICSID, ALBA stated: "States of the ALBA-TCP agree to withdraw and report jointly to the ICSID Convention guaranteeing the sovereign right of countries to regulate foreign investment in its territory.” [18]

On May 2, 2007 Bolivia formally notified the ICSID Secretariat of the denunciation of the ICSID Convention

\footnotetext{
${ }^{11}$ Mexico is the only country in Latin America that retains an unaltered Calvo Doctrine in it Constitution Art. 27 and has not joined ICSID nor MIGA. Mexico presents an interesting contrast as the state has had to defend against, and is currently involved in, a number of ICSID disputes where foreign investors have triggered arbitral proceedings under the NAFTA. Except for its obligations under NAFTA and other treaty commitments, however, Mexico's Investment Law is considered to be among the more restrictive. This law does not provide for Mexico's consent to submit disputes to arbitration. Furthermore, the law is generally restrictive and provides that a number of "economic activities and enterprises...shall be limited to" maximum amounts of foreign ownership. Another group of activities require special approval of the foreign investment commission if the foreign investor is to own more than $49 \%$ Moreover, the registration procedure is burdensome, there are limits on the foreign ownership of property, and there are various sanctions that can be imposed on foreign investors who breach the provisions of the law [15].

${ }^{12}$ Its name in Spanish is Alianza Bolivariana para los Pueblos de Nuestra América Tratado de Comercio de los Pueblos. Its current members are Antigua and Barbuda, Bolivia, Cuba, Commonwealth of Dominica, Ecuador, Honduras, Nicaragua, Saint Vincent and the Grenadines, and Venezuela. Haiti and Uruguay are currently observer states [17].
}

[16] and on December 4, 2007 Ecuador sought to limit the ICSID jurisdiction in disputes arising from natural resources investments, including oil, gas, mineral and others by resorting to Article 25(4) of the ICSID Convention [19].

After Bolivia announced its withdrawal from ICSID, the President of Venezuela Hugo Chávez similarly announced that the country would also be withdrawing from the ICSID Convention [10]. In spite of the fact that on 12 February 2008, the Venezuelan National Assembly recommended that the Executive withdraw from the ICSID Convention [20], the Venezuelan government has not yet to notify ICSID of its withdrawal.

On April 14, 2008 Nicaragua's Attorney General reiterated that it was considering denouncing the ICSID Convention, citing Argentina's recent experience and indicating that Nicaragua would not sign investment agreements which provide for ICSID as the competent tribunal going forward [20].

On July 2, 2009 the Ecuadorian President Correa by Executive Decree 1823 announced the withdrawal from ICSID, referring the aforementioned Article 422 of Ecuadorian Constitution [21] and on July 62009 ICSID received Ecuador's notification of denunciation, which was effective on January 7, 2010 [16].

In 2009 during the 7th ALBA-TCP Summit, it was proposed the creation of a regional arbitration centre to replace ICSID, instructing a dispute resolution group to work on this issue and develop concrete alternative proposals in the near term [2]. So far, however, this arbitration centre has not been created. Together with ALBA's proposal, similar initiative is being developed in Latin America, such as the proposal of Ecuador for the creation of the Arbitration Centre within UNASUR.

\section{Analysis of Some Latin America Countries' Countermeasures against ICSID Arbitrations}

\subsection{Plurinational State of Bolivia (Bolivia)'s Countermeasures}

On May 1, 2006, one of the first measures taken by President Evo Morales was to issue the Decree 28701 [22] which nationalized the entire hydrocarbon industry. ${ }^{13}$ The following day, President Morales militarized the oil \& gas field to ensure the enforcement of the Decree [23]. Exactly a year later, Bolivia formally notified the ICSID Secretariat about the denunciation of the Washington Convention, being the first contracting State that denounced it (in accordance with Article 71 of the ICSID

\footnotetext{
${ }^{13}$ It is necessary to consider the Evo Morales's rise to the presidency of Boliva is widely seen as having been buttressed by the massive protests in Cochabamba in reaction to the privatization programms of the IMF and World Bank. [10].
} 
Convention, the denunciation took effect on November 3, 2007).

The World Bank website mentions that Bolivia expressed the following arguments against ICSID: “1. Their decisions are final i.e. there is no appeal. 2. It is not neutral. Of 232 cases, 230 have been in favour of firms against the state. 3 . The ICSID interference contradicts the Bolivian Constitution (Article 135) and the Constitutional Tribunal has already declared it incompetent. 4. Only demands of firms are presented at the body. 5 . Their methodology is unclear and arbitrary. 6. It doesn't accept audiences with external petitions. It meets behind closed doors. 7. The defense of the State ends up being very costly, given the necessity to contract lawyers in the United States. It is said that every case costs the State 4 million dollars.” [11] Furthermore, Bolivia announced the renegotiation and revision of its BITs [24].

After the process of nationalization, Bolivia faced demands from transnational corporations before international arbitrations without an executive branch to preserve and defend the interests of the country. It was in this context, from June 5, 2008 to February 9, 2009, the Bolivian Government established a new Ministry, responsible for the legal defense of the State (Ministerio Sin Cartera Responsable de la Defensa Legal de las Recuperaciones Estatales) by Presidential Decree N 29589 [25].

In 2009 Bolivia approved by referendum a new Constitution that includes the famous "Calvo Clause," providing in Article 366 that the foreign investment in particular for activities in the oil and gas industry are subject to the laws of Bolivia and forbids them to recourse the foreign tribunals or jurisdiction. These constitutional provisions do not apply retroactively, nor to any dispute arising out of treaties ratified before the change of the Constitution [26].

At that moment, the Constituent Assembly noted the necessity for the creation of the Attorney General Office that preserves and protects the State's interests. Thus, the Government of Evo Morales established the Ministry of State's Legal Defense (regulated by Supreme Decree No. 29894) [27] and is implemented the Office of Attorney General [28].

The implications of Bolivia's denunciation of the ICSID Convention remain unclear for foreign investors because the Convention's provisions on denunciation are the source of contradictory interpretations in connection with the denunciation of the it and with the termination of BITs, as to whether the denouncing State remains bound by the Convention only in relation to disputes initiated before the denunciation (called "theory of offer to consent), or also in relation to future disputes as long as the State's consent to ICSID arbitration continues to exist in that country's BITs (called "theory of consent"). This latter reading effectively means that for a State to prevent future ICSID claims, it must not only withdraw the ICSID Convention but also separately terminate all of its BITs that contain an ICSID arbitration option. Moreover, under this interpretation, exposure to ICSID proceedings will persist as long as the terminated BITs retain their force due to the "survival clauses", e.g. up to 20 years after the termination.

In relation with this issue, the case Pan American Energy LLC v. Plurinational State of Bolivia will resolve these contradictory interpretations because this arbitration was registered by ICSID on 12 April 2010. ${ }^{14}$ Until August 20, 2011 the Arbitration Tribunal has not yet been constituted in this case. It will be important to follow it to know the position of ICSID in relation with the provisions on denunciation.

\subsection{Republic of Ecuador's Countermeasures}

After assuming office in 2007, President Correa announced his decision to halt talks about free trade agreement with the United States. On October 2007 his administration imposed a new tax on many foreign oil companies operating in Ecuador [23]. Probably, to avoid a wave of new claims related to oil \& gas. On December 4, 2007 Ecuador sought to escape ICSID jurisdiction by resorting to Article 25 (4) of the ICSID Convention, providing for the exclusion of "[...] differences arising on matters concerning the treatment of an investment, resulting from economic activities concerning the use of natural resources such as oil, gas, minerals or other [...].” [19]

In order to understand the effect of the notification of the Article 25(4), it is necessary to undertake an analysis on the issue of consent similar to the one performed with Bolivia's denunciation of ICSID Convention. Under the "theory of offer to consent" Ecuador would no longer be bound to appear before ICSID in cases that have not been filed prior to the notification of the formal exclusion, even if the investments were made before the exclusion, and under the coverage of a BIT that is still in force.

In 2008 Ecuador adopted a new Constitution in which Article 422 expressly prohibits the Ecuadorian State entering into international agreements under which Ecuador would have to cede jurisdiction to international arbitral tribunals in contractual or commercial controversies between the State and individuals or corporations. It is, however, important to note that Article 422 forbids only the signature of new international treaties and it does not restrict other agreements from including an arbitration

\footnotetext{
${ }^{14}$ See Pan American Energy LLC v. Plurinational State of Bolivia (ICSID Case No. ARB/10/8) [1].
} 
clause. Moreover, in an effort to promote Latin America as a site for international arbitrations, Article 422 does not prohibit Ecuador from entering into international arbitration treaties requiring disputes between Ecuador and citizens of Latin America to be submitted to arbitration, as long as those disputes are submitted to regional arbitral bodies within the Latin American continent [29].

In the same year, Ecuador terminated eight BITs which were deemed to be unsuccessful in stimulating new investments and in October 2009, President Rafael Correa proposed to the National Congress that Ecuador should withdraw from additional BITs dating from the 1990s. These include Ecuador's BITs with six conventional capital exporters in Europe and North America (U.S., U.K., Germany, France, the Netherlands, and Canada) as well as China [30].

On July 2, 2009 Ecuadorian President Correa by Executive Decree 1823 announced the withdrawal from ICSID referring to the aforementioned Article 422 of the Ecuadorian Constitution [21] and on July 6, 2009, ICSID received Ecuador's denunciation of the Convention (on January 7, 2010 the denunciation was effective). It is important to consider that in 2010, based on the Ecuadorian Constitution, Article 422, the Ecuadorian Constitutional Court declared the unconstitutionality of some BITs and decided to continue with the denunciation proceedings, including the China-Ecuador BIT [31].

Since 2009 Ecuador has lead a movement to create a regional arbitration forum under the auspices of UNASUR to deal with investment disputes [32].

\subsection{Bolivarian Republic of Venezuela (Venezuela)'s Countermeasures}

On August 18, 1993 Venezuela signed the ICSID Convention and it entered into force on 1 June 1995 [16].

When President Chávez took office in February 1998, he promised a major reform of the National Constitution and the installation of a new economic system. In 1999, a new Constitution was passed by the National Constituent Assembly. The Chávez’s administration gradually implemented major legal reforms, including the enactment of a new Hydrocarbons Law in 2001, through the implementation of the programs Plena Soberanía Petrolera (Full Petroleum Sovereignty) [33] and Siembra Petrolera (Planting Petroleum) [34]. These programs involved the renegotiation of the oil contracts with private investors and a consequent dramatic increase of the country's share in the profits. Some investors resisted the mandated change from a private to a mixed corporate form, with a majority stake in the hands of the State [23].

After Bolivia announced its withdrawal from ICSID, the President of Venezuela Hugo Chávez similarly announced that the country would also be withdrawing from the ICSID Convention [10]. In spite of the fact that on 12 February 2008, the Venezuelan National Assembly recommended that the Executive withdraw from the ICSID Convention [20]. the Venezuelan government has not yet notified ICSID of its withdrawal. Moreover, in the same year Venezuela took some antiarbitration measures, directly targeted at potential claims that could arise out of the expropriations and nationalizations.

Venezuela denounced its BIT with Netherlands on April 30th, 2008 [35] and on October 17, 2008, the Supreme Tribunal by the Decision No 1541 [36], resolved that Article 22 of the Law for the Promotion and Protection of Investment did not contain a unilateral general declaration of consent to ICSID jurisdiction. This Decision was delivered by the Venezuelan Supreme Tribunal, which is the only court whose decisions set binding judicial precedent (erga omnes effects). An interesting aspect about this Decision is that it was rendered after a petition for the interpretation of Article 258 of the National Constitution, ${ }^{15}$ filed by representative of Venezuela's Attorney General Office. The object of the Attorney General's petition was to limit the constitutional reach of the Law Concerning the Promotion and Protection of Investment (LPPI) Article 22. Thereby excluding any consent of the State to arbitration on the basis of a unilateral consent contained in the Article 22 of the LPPI, that states: "Any dispute arising between an international investor whose country of origin has in effect an agreement for promotion and protection of investments with Venezuela or any disputes to which the provisions of the Articles of Association of the Multilateral Investment Guarantee Agency (MIGA) or the Convention on the Settlement of Investment Disputes between States and Nationals of Other States (ICSID) shall be submitted to international arbitration under the terms provided for in the respective treaty or agreement, should it so provide, without prejudice to the possibility of using the systems of litigation provided for in the Venezuelan laws in force, when applicable.” [23]

On June 10 2010, coinciding with the Supreme Tribunal's Decision No 1541, the ICSID Tribunal in Mobil Corporation and others $\mathrm{v}$ Bolivarian Republic of Venezuela issued its Decision on jurisdiction, stating that the domestic legislation did not, by itself, represent a general consent to arbitration. It did, however, have jurisdiction over certain of Mobil's claims as a result of the BIT. ${ }^{16}$

\section{UNASUR Arbitration Centre. Analysis of the Ecuador's Proposal}

On 23 May 2008, the “Constitutive Treaty of UNASUR”

\footnotetext{
${ }^{15}$ Venezuela's National Constitution Article 258: “[...] The law shall encourage arbitration, conciliation, mediation and any alternative means of conflict resolution.”
} 
[37] was signed by Argentina, Bolivia, Brazil, Chile, Colombia, Ecuador, Guyana, Paraguay, Peru, Suriname, Uruguay and Venezuela. On March 11, 2011 this treaty entered into force [38]. The fact that UNASUR has now come into formal existence is a significant development and it is the first regional institution for some time that represents all South American countries [39].

In June 2009 many Latin American countries were dissatisfied with ICSID. At the thirty ninth Session of the General Assembly of the Organization of American States, Ecuador's Foreign Minister, Fander Falconí, proposed that UNASUR create an Arbitration Centre [2].

During the V Summit of Judicial Powers of UNASUR, from 23 to 25 June 2010 the Presidents and Representatives of the Judiciary Branch of the Republics of Bolivia, Brazil, Chile, Colombia, Ecuador, Guyana, Paraguay, Peru, Uruguay and Venezuela, with Cuba as guest country, recommended the inclusion in the Agenda of the VI Summit of Judicial Powers of UNASUR the proposal to study the creation of the Consultative Council of Justice of UNASUR and the International Centre for Conciliation, Mediation and Arbitration for the region [40].

In December 2010 in Guyana, the Foreign Ministers of the UNASUR member countries unanimously decided that Ecuador chair the working group of the "Dispute Settlement System.” In this context, Ecuador submitted a proposal for the creation of this system, which had been researched and will be discussed during 90 days from the first meeting.

The Ecuadorian proposal to create a system of alternative dispute resolution is contained in three documents: 1 . Creation of an Arbitration Centre, 2. A Code of Conduct for Arbitrators and Mediators of UNASUR and 3. Counseling Centre of Investment Disputes. ${ }^{17}$

In relation to the Arbitration Centre, it specifies that it shall be independent and be constituted by Centre Board (integrated by representatives of member States) and the General Director. The Chair of the Centre Board shall be exercised by the country holding the Presidency ProTempore of UNASUR.

The Operating Rules of UNASUR Arbitration Centre, allows settlement of disputes between States and between

\footnotetext{
16“"Finally, the Tribunal notes that Mobil Corporation has only raised claims on the basis of Article 22 of the Investment Law and not on the basis of the BIT. In $\S 140$ above, the Tribunal has concluded that Article 22 of the Investment Law does not provide a basis for jurisdiction in the present case. As a consequence, the Tribunal has no jurisdiction over the claims of Mobil Corporation, which will thus not be a Party to the continuation of these proceedings.” Mobil Corporation and others v. Bolivarian Republic of Venezuela (ICSID Case No. ARB/07/27) Decision on Jurisdiction (June 10, 2010), at para 207.

${ }^{17}$ In May 2011 this documentation has been obtained from the UNASUR's member of the working group for the negotiation of this proposal.
}

a State and investor as are referred to it by virtue of any contractual provision or provision in an international instrument (Article 2). The jurisdiction of the Centre precluding disputes concerning health, education, taxation, energy, the environment and others, unless expressly stated otherwise in the relevant treaty or contract. In no circumstances an arbitral tribunal will have jurisdiction to resolve disputes concerning the internal laws of a UNASUR member State. This preclusion also extends to the economic effects of a general norm. Although the jurisdiction of UNASUR Centre is not only confined to investment, this stipulation considerably reduces some matters that are connected with investment and commerce.

The States can require, as a precondition for the arbitration, the exhaustion of domestic judicial and administrative remedies. In circumstances where a claim arises in relation to an administrative act of a State, it will always be necessary to exhaust domestic remedies (Articles 3). The requirement to exhaust the administrative and domestic judicial remedies could force the injured party to wait years until applying to the UNASUR Centre. It would be necessary to state a reasonable limit of time for the conclusion of the domestic proceedings to give certainty and security to the parties and ensure the success of this Arbitration Centre.

The parties shall endeavour to resolve any dispute by consultations that are considered to be concluded within 6 months from the date of filing the request, unless the parties agree to continue with them. They are not mandatory so the parties cannot implement them by mutual agreement and go directly to the stage of mediation (Article 4). It will be important at this stage to consider the success of the WTO's consultant to resolve disputes between States. A majority of disputes in the WTO have not proceeded beyond consultations (until 1 January 2010 there have been 402 complaints and only 126 panel reports in the WTO). Thus, it is recommended that this stage would be mandatory for disputes between States but not for State and investor disputes because in the latter case, the parties are not equal in negotiating without the intervention of a third person such as mediator or arbitrator.

The mediation is closed when the parties sign a settlement agreement, by decision of the mediator if in his/ her opinion considered unlikely that the continuation of mediation to settle the dispute or by written decision of any party at any time after attending the first meeting with the mediator and before signing any settlement agreement (Article 5).

In the case of a dispute between an investor and a State, the investor shall notify the State before initiating the arbitration process. The State of the investor may initiate 
a process of mediation between the investor and the State party to the disputes. The parties by mutual agreement may dispense with the mediation process initiated by the State (Article 6).

The Tribunal shall be composed of three arbitrators, unless the parties decide that another odd number would be appropriate. Each party shall appoint one arbitrator and both parties shall designate by common agreement the president and his/her substitute of the Tribunal within 30 days. If the parties have not selected an arbitrator or there is no agreement on the selection of the president of the tribunal, Directorate General of the Centre shall designate him/her by lot (Article 9).

Any party may challenge any arbitrator during the election of the arbitrators if any circumstances giving rise to justifiable doubt about their impartiality, independence and compliance with the Code of Conduct. Within 5 days of the challenge, the disputing parties may agree to accept the challenge. In that case the challenged arbitrator shall resign. If there is no agreement between the parties to accept the challenge, the Directorate General of the Centre shall decide the recusal within 5 days (Article 10).

During the proceedings, when any party considers that an arbitrator does not meet the requirements of the Code of Conduct and for that reason should be replaced, that party shall notify the other party within 15 days from the date on which the party took cognizance of the violation of the Code of Conduct by the arbitrator. If the arbitrator replaced is not the president of the tribunal, the parties can reach an agreement to replace him/her and shall elect a replacement following the procedure of Article 9. If the parties fail to reach agreement, they shall request that the matter be raised to the President, whose decision shall be final.

If the president does not meet the requirements of the Code of Conduct and there is no agreement between the parties, either party may request that the matter shall be decided by one member of the list of arbitrators, chosen by lot. If this arbitrator decides that the president of the arbitral tribunal does not meet the requirements of the Code of Conduct, the arbitrator shall choose a new president of the tribunal arbitral by lot (Article 12). In relation to the requirements of independent judgment and the disqualification of the arbitrator, the Ecuador proposal responds to the observations made to ICSID and significantly improves the regulation in this issues, that is similar to International Chamber of Commerce and Stockholm Chamber of Commerce Arbitration (SCC) Rules but with a particular characteristic as the selection by lot.

The exclusivity of this Arbitration Centre is established by Article 19. It states that when parties decide to submit a dispute before UNASUR Arbitration Centre, they renounce the use of another alternative forum for disputes related to the same matter (i.e. when referring to the same parties on the same facts or the same measures). This is to avoid the "shopping claims" that happen nowadays but it will be difficult to do because the investor can sue a State but cannot force its shareholders, who using the BITs, contract and legislation can sue in another forum.

In order to avoid inconsistent decisions and awards, the arbitral tribunal shall consolidate two or more proceedings in which discussions of the common question of fact or law on the same measure or decisions. The parties may submit to the tribunal their arguments for the consolidation of claims (Article 22). It would be necessary to consider the NAFTA Rules to permit a tribunal feasibility evaluation on a case by case basis.

In relation to the transparency of the proceedings, any arbitration shall be public (this includes documents, records, evidence, hearings and awards) except for those relating to defense and security of States and the special cases which the parties determine by mutual agreement. (Articles 23 and 26). In this issue, the proposed regulation is consistent with the current requirements of more transparency in these kinds of proceedings such has been adopted by NAFTA Rules, but it is necessary to specify that the party also has the right to request confidentiality of certain documents such as business secrets.

For amicus curiae, unless the parties agree otherwise, following the conformation of the tribunal, it can receive unsolicited letters from individuals or legal entities established in the territories of the parties when delivered within 10 days from the date of the tribunal constitution. The amicus curiae need to be concise and directly addressing issues relevant to matter of fact and law submitted to the tribunal Arbitration's consideration (Article 35). The time limit to receive amicus curiae is very short; it should be modified until the submission of the allegations.

In relation to the award, it shall be decided within a period of 240 days from the date of the constitution of the tribunal, extendable up to 120 days with the agreement of the parties (Article 41). Moreover, the awards shall be published and have precedential value (Articles 21 and 26). The consistency and coherence of jurisprudence create predictability and enhance the legitimacy of the investment arbitration's system. ICSID lacks this feature.

The awards rendered under the UNASUR Arbitration Tribunal can be attacked by rectification, revision, annulment and appellation. The application for annulment may be based on the following grounds:

1. The arbitral tribunal was not properly constituted.

2. It manifestly exceeded its powers. 
3. A tribunal member was corrupt.

4. There was a serious departure from a fundamental rule of procedure.

5. The award did not state the reasons upon which it was based.

The application for annulment shall be decided by Tribunal Arbitration Ad-doc and maximum period for resolving is 60 days from the date of its conformation (Article 42).

An appeal can be submitted against the award through the review of questions of law and an Appellate Tribunal shall decide preferably by consensus. Eight arbitrators would constitute the pool for the appeal tribunal, which would be comprised of three arbitrators for any given case. The appeals would have to be decided within 60 days from the Appellate Tribunal's constitution (Article 44). The enforcement regime envisaged by the centre demands parties to comply immediately with an award, or in the event this is not possible, within a time frame agreed by the parties. Such time limit can be extended to 180 days in the event of justifiable circumstances, such as civil or economic emergencies (Article 46).

The only basis for denying recognition and enforcement of the award would be when, in accordance with the host State's Constitution or its law, the subject of the dispute is not arbitral or is contrary to public policy (Article 47). In the event that the award is not honored, the matter shall be returned to the original arbitral tribunal that heard the dispute. Subject to certain criteria, in the investor-State disputes where the respondent State does not comply (wholly or partially) with the award, the home State may temporarily suspend concessions and obligations owed to the host State, in the sector that is relevant to the dispute. Such suspension would have to be proportional to the degree of non-compliance (Article 49).

In relation to the Counseling Centre, it will provide legal guidance, technical assistance, research, specialized studies and legal representation in terms of investment disputes (Article 2). In the event of a conflict of interest, when the antagonistic parties are among countries that are part of UNASUR and the Centre, the Centre is disallowed to provide its services (Article 3).

Both the Arbitration Centre and the Counseling Centre will have an initial stage of use only for countries that are part of UNASUR for a period of 3 years. A second stage, from the start of the third year of the centre's existence, may use its services in Central America and the Caribbean and in the final stage, from the sixth year onwards; it will be open to any country wishing to use it. The Arbitration Centre and the Counseling Centre will have different stages of implementation. This gradual process of implementation will facilitate steady development of the Arbitration and the Counseling Centre.

With regards to the Code of Conduct for Arbitrators and Mediators of UNASUR member States in Article 3, like UNCITRAL Rules and SCC Rules, provides that an arbitrator shall disclose during all the proceedings any "interest, relation or issue that may affect the independence or impartiality or that might reasonably create an impression of dishonest or unfair behavior in the process.” It is necessary to consider that the independence and impartiality, are very closely related terms, and often used as synonyms, however the concepts are different and should be distinguished. The independence is an objective question and impartiality is subjective. Most would agree that independence is the absence of actual identifiable relationships with a party to proceedings. As it is an objective test there is no need to prove the effect of any relationship on the arbitrator, merely its existence. In contrast impartiality is concerned with whether an arbitrator is actually favoring one of the parties. The test for impartiality examines the likelihood of an arbitrator actually having a state of mind or prejudgment that favors one side in the dispute [41]. Thus, the disquisition realized in Code of Conduct for Arbitrators and Mediators of UNASUR mentioning independence and impartiality (in its Article 3 and 5 (1)) is very important when the parties decide to challenge the arbitrator. Furthermore, it states that former arbitrators shall not affect the subsequent tribunal decisions nor publicly comment on cases similar to those that they already decided (Article 6).

\section{Conclusions}

ICSID arbitration has lacked the guarantee of due process because of its impartial and not transparent proceedings, failure to address the broader needs of society as well as generally inconsistent decisions and awards, the lack of hierarchy of investment tribunals and no system of precedent or appeals.

Thus, some of Latin American Countries are changing their position on ICSID and are considering reviving some aspects of the Calvo Doctrine. The most critical examples of recent hostility are found in the cases of the ALBA declaration, the denunciation of ICSID Convention by Bolivia and Ecuador, Venezuela's anti-arbitration measures and the proposal to study the creation of an Arbitration Centre in the UNASUR. Additional examples are Argentina's experience with investment arbitration as the most sued country in ICSID, the fact that Brazil (the most successful country in Latin America attracting flows of FDI) is not a signatory of the ICSID Convention nor has it ratified any of the BITs executed during the 1990s, that Mexico still seems reluctant to enter the ICSID system notwithstanding its being part of NAFTA. All these situations suggest that the willingness to create 
a regional Arbitration Centre within UNASUR will be a firm and slow process, facing a lot of internal and external political obstacles.

On the matter of Ecuador's proposal to constitute the UNASUR Arbitration Centre, it would need to be reconsidered in regard to some critical points, i.e. the limitation of the Arbitration Centre's jurisdiction and state a reasonable limit of time for the requirement to exhaust domestic judicial remedies and consider the NAFTA Rules in relation to the consolidation claims. However, it is important to note that this proposal improves the transparency and consistency of decisions by the establishment of an appeal mechanism with a system of precedent. It included all the observations made to the ICSID proceedings by Latin American countries. Furthermore, the influence of the WTO's dispute settlement system regarding the consultation stage, appellation proceedings and the award compliance (the WTO's compliance levels appear to be fairly high [42]) are all remarkable.

Despite the observations concerning UNASUR Arbitration Centre mentioned above, if Ecuador's proposal is adopted by Latin American countries, it could jeopardize the future of ICSID.

\section{REFERENCES}

[1] International Center for Settlement of Investment Disputes, "Search ICSID Cases,” 2011. http://icsid.worldbank.org/ICSID/FrontServlet?requestTy $\mathrm{pe}=$ CasesRH\&reqFrom=Main\&actionVal=ViewAllCases

[2] K. F. Gómez, "Latin America and ICSID: David versus Goliath?” Research Paper, University of Zaragoza, Zaragoza, 2010. http://ssrn.com/abstract=1708325

[3] M. H. Mourra, Concluding Note, In: M. H. Mourra, Ed., Latin American Investment Treaty Arbitration. The Controversies and Conflicts, Kluwer Law International BV, 1st Edition, The Netherlands, 2008, p. 196.

[4] U.S.-China Economic \& Security Review Commission, "Backgrounder: China in Latin America," Research Report, 2011, pp. 9-10.

http://www.uscc.gov/Backgrounder_China_in_Latin_Am erica.pdf

[5] S. Rodriguez-Jimenez, "El CIADI Frente a la Argentina, México, Ecuador y Bolivia. Una actualización,” Research Paper, Instituto de Investigaciones Jurídicas de la UNAM, México, p. 244.

http://www.bibliojuridica.org/libros/6/2815/13.pdf

[6] S. D. Franck, "Development and Outcomes of Investment Treaty Arbitration,” Harvard International Law Journal, Vol. 50, No. 2, 2009, pp. 443-444. http://ssrn.com/abstract $=1406714$

[7] S. P. Kumar, "Rethinking the Linkages between Foreign Direct Investment and Development: A Third World Perspective,” NALSAR Student Law Review (E-Journal), Vol. 31, 2009, p. 38.
http://www.nalsarstudentlawreview.com/files/Shashank.p df

[8] A. Sheppard, "Arbitrator Independence in ICSID Arbitration,” In: C. Binder, U. Kriebaum, A. Reinisch and S. Wittich, Eds., International Investment Law for the 21st Century, Oxford University Press, New York, 2009, p. 132. doi:10.1093/acprof:oso/9780199571345.003.0010

[9] N. Rubins and B. Lauterburg, "Independence, Impartiality and Duty of Disclosure in Investment Arbitration,” In: C. Knahr, C. Koller, W. Rechberger and A. Reinisch, Eds., Investment and Commercial Arbitration-Similarities and Divergences, Eleven International Publishing, The Netherlands, 2010, p. 172.

[10] M. H. Mourra, "The Conflicts and Controversies in Latin American Treaty-Based Disputes,” In: M. H. Mourra, Ed., Latin American Investment Treaty Arbitration, Kluwer Law International BV, 1st Edition, The Netherlands, 2008.

[11] World Bank Group, "Bolivia leaves the ICSID," http://web.worldbank.org/WBSITE/EXTERNAL/BANC OMUNDIAL/EXTSPPAISES/LACINSPANISHEXT/BO LIVIAINSPANISHEXT/0,print:Y isCURL:Y contentM DK:22766950 pagePK:1497618 piPK:217854 theSiteP K:500410,00.html

[12] “CIADI/Telecom Italia: ¡hands off Bolivia!” pp. 16-17. http://www.cadtm.org/IMG/pdf/ICSID_TI_Hands_off_B olivia.pdf

[13] D. S. Bernal, "International Arbitration in Latin America," Comparative Commercial Law, 2009, pp. 5-6. http://www.natlaw.com/interam/mx/ad/sp/sparad00002.p df.

[14] G. Biggs, "The Latin American Treatment of International Arbitration and Foreign Investments and the ChileU.S. Free Trade Agreement," ICSID Review. Foreign Investment Law Journal, Vol. 19, No. 1, 2004, p. 68.

[15] T. J. Pate, “The Past, Present and Future of the Arbitral Clause in Foreign Investment Legislation: In Pursuit of The Balance," Research Paper, pp. 73-74.

http://www.desolapate.com/publicaciones/The\%20Past\% 20Present\%20and\%20Future\%20of\%20the\%20Arbitral\% 20Caluse\%20in\%20Foreign\%20Investment\%20Legislati on,\%20In\%20Pursuit\%20of\%20The\%20Balance.pdf

[16] International Center for Settlement of Investment Gisputes, "List of Contracting States and Other Signatories of the Convention," 5 May 2011.

http://icsid.worldbank.org/ICSID/FrontServlet?requestTy $\mathrm{pe}=$ ICSIDDocRH\&actionVal=ShowDocument\&language =English

[17] Bolivarian Alliance for the Peoples of our American Peoples’ Trade Treaty. http://www.alba-tcp.org

[18] Decision of Bolivarian Alliance for the Peoples of our American Peoples' Trade Treaty about International Center for Settlement of Investment Disputes, 2 May 2007. http://www.sns.gob.bo/institucional/pag-doc/para\%20la\% 20pagina\%20WEB\%20Antitransparencia/ALBA/ALBATCP/ALBA_TCP_001/ANEXO_001_IV.pdf

[19] "Ecuador's Notification under Article 25(4) of the ICSID Convention,” 23 November 2007. 
http://icsid.worldbank.org/ICSID/FrontServlet?requestTy pe=ICSIDPublicationsRH\&actionVal=ViewAnnouncePD F\&AnnouncementType=regular\&AnnounceNo=9.pdf

[20] S. Noury and C. Richard, “International Arbitration in Latin America: Overview and Recent Developments. International Arbitration 2008. A practical insight to crossborder International Arbitration work: Chapter 38," Global Legal Group, 2008. http://www.iclg.co.uk/khadmin/Publications/pdf/2574.pdf

[21] “Executive Decree 1823/2009,” Article 1. http://www.sigob.gov.ec/decretos/decretos.aspx?id=2007

[22] “Supreme Decree No. 28701,” Articles 1, 2, 5, 6 and 7. http://www.offnews.info/downloads/decreto_bolivia.pdf

[23] I. Vincentelli, "The Uncertain Future of ICSID in Latin America," Independent Research Paper, University of Miami School of Law, 2008. http://ssrn.com/abstract=1348016

[24] Bolivian Movement for the Sovereignty and the Solidarity Integration of the Peoples: Against NAFTA and the FTAA, "Bolivia inicia campaña internacional contra el CIADI: renegociará 24 tratados de protección a las inversiones," May 2007.

http://www.boliviasoberana.org/blog/_archives/2007/5/9/ 2937469.html

[25] Presidential Decree No. 29589, Articles 1 and 2, June 5, 2008.

http://www.gacetaoficialdebolivia.gob.bo/normas/verGrat is/27104

[26] A. van Aaken, "International Investment Law and Rationalist Contract Theory,” Dissertation in NYU School of Law: IILJ International Legal Theory Colloquium Spring 2009 Virtues, Vices, Human Behavior and Democracy in International Law, 2009, p. 24.

http://www.iilj.org/courses/documents/2009Colloquium.S ession2.Aaken.pdf

[27] Supreme Decree N. 29894 - DOE, Articles 13 and 42. http://www.sns.gob.bo/documentacion/normativas/Estruct ura\%20organizativa\%20del\%20Poder\%20Ejecutivo\% 20del\%20Estado\%20Plurinacional.pdf

[28] Attorney General's Office. Plurinational State of Bolivia, “Objetivos Institucionales,” 2011. http://www.procuraduria.gob.bo/index.php/objetivos-insti tucionales.html

[29] C. Coronel-Jones, "The future of international arbitration in Ecuador: the boomerang effect,” 22 July 2010. http://www.internationallawoffice.com/newsletters/detail. aspx?g=e46353d6-6931-47da-9acd-a187dcf9cf84.

[30] G. Van Harten, "Five Justifications for Investment Treaties: A Critical Discussion,” Trade, Law \& Development Vol. 2, No. 1, 2010, p. 4. http://ssrn.com/abstract $=1622928$

[31] Constitutional Court, Case No. 0004-10-TI, Decision No. 027-10-DTI-CC, 29 July 2010, p. 26. http://186.42.101.3/alfresco/d/d/workspace/SpacesStore/6 2d8f4a1-3f78-4f8a-b1d3-1604f8e9e2f2/0004-10-TI-res.p df

[32] F. C. Diaz, "Ecuador prepares for life after ICSID, while debate continues over effect of its exit from the Centre," 28 August 2009.

http://www.iisd.org/itn/2009/08/28/ecuador-prepares-for-l ife-after-icsid-while-debate-continues-over-effect-of-its-e xit-from-the-centre/

[33] Venezuela's Government, Ministry of Popular Power for Energy and Petroleum, "Plena Soberanía Petrolera. Una política popular, nacional y revolucionaria,” Speeches Series 2, 20 Octubre 2005.

http://www.pdvsa.com/interface.sp/database/fichero/publi cacion_opep/2376/169.PDF.

[34] Venezuela's Government, Ministry of Popular Power for Energy and Petroleum, "Plan Siembra Petrolera 2005-2030,” pp. 4-6.

http://www.pdvsa.com/index.php?tpl=interface.sp/design/ readmenuprinc.tpl.html\&newsid_temas=32

[35] R. R. Quijada, "The "Survival Clause" in the Netherland Venezuelan BIT: A Salvation Gateway for Foreign Investment in the oil Sector or a Curse for the Venezuelan Government?" Research Paper of University of Dundee, p. 5, CAR-12_29_26223666_0-2.pdf.

[36] Supreme Court, Case No. 08-0763, Decision 1541, 17 Oc- tober, 2008, para. 124.

http://www.tsj.gov.ve/decisiones/scon/octubre/1541-1710 08-08-0763.htm

[37] "Union of South American Nations Treaty," Articles 1 and 3.

http://www.pptunasur.com/downloads/tratado-constitutiv o-UNASUR.pdf

[38] The Universe, "Cancilleres Sudamericanos Pusieron en Vigencia Tratado de la UNASUR,” 11 March 2011. http://www.eluniverso.com/2011/03/11/1/1355/cancillere s-sudamericanos-pusieron-vigencia-tratado-unasur.html

[39] C. Leathley, "What will the recent entry into force of the UNASUR Treaty mean for investment arbitration in South America?” Network for Justice in Global Investment, April 2011.

http://justinvestment.org/2011/04/what-will-the-recent-en try-into-force-of-the-unasur-treaty-mean-for-investment-a rbitration-in-south-america/

[40] Ministry of Justice Human Rights and Religious Affairs of Ecuador. "Declaración Final de Cumbre de Poderes Judiciales de UNASUR,” 25 June 2010.

http://www.minjusticia-ddhh.gov.ec/index.php?option=co m_content\&view=article\&id=2518:declaracion-final-de-c umbre-de-poderes-judiciales-de-unasur\&catid=276:institu cionales\&Itemid $=59 \% 27$

[41] C. Kee, "Judicial Approaches to Arbitrator Independence and Impartiality in International Commercial Arbitration," In: C. Knahr, C. Koller, W. Rechberger and A. Reinisch, EdS., Investment and Commercial Arbitration-Similarities and Divergences, Eleven International Publishing, The Netherlands, 2010, pp. 183-184.

[42] A.T. Guzman, "International Tribunals: A rational choice analysis," University of Pennsylvania Law Review, Vol. 157, No. 171, 2008, p. 197. http://www.pennumbra.com/issues/pdfs/157-1/Guzman.p df 